\title{
Potential of Mid-Rise Social Residential Buildings to Reach Net Zero Energy Building Standard in Two Different Climates of Chile
}

\author{
Felipe Tori ${ }^{1,2,4}$, Sergio Vera ${ }^{1,2,4}$, Waldo Bustamante ${ }^{2,3,4}$, Pablo Sills ${ }^{5}$ \\ ${ }^{1}$ Department of Construction Engineering and Management, School of Engineering, Pontificia \\ Universidad Católica de Chile, Santiago, Chile \\ ${ }^{2}$ Center for Sustainable Urban Development (CEDEUS), Santiago, Chile \\ ${ }^{3}$ School of Architecture, Pontificia Universidad Católica de Chile, Santiago, Chile \\ ${ }^{4}$ UC Energy Research Center, Santiago, Chile \\ ${ }^{5}$ Universidad Técnica Federico Santa María, Valparaíso, Chile
}

\begin{abstract}
The Net Zero Energy Buildings (NZEB) are a real solution to reduce the energy consumption and greenhouse gas (GHG) emissions generated by the building sector. Thus, many developed countries have conducted different studies for the development of public policies that encourage the implementation of NZEB. Chile adopted as environmental goal for the coming years reducing the GHG emissions by $30 \%$, but the instruments to accomplish them have not been clearly defined. The NZEB might be a key strategy to reduce the GHG emissions. However, there are no studies that evaluate the performance of NZEB in Chile. The aim of this research is to determine the potential of mid-rise social residential buildings to reach the NZEB standard in Santiago and La Serena. In particular, mid-rise social buildings are selected as representative for this study through the use of a multi-criteria matrix. The electric consumption of buildings and photovoltaic production are simulated in EnergyPlus. The optimizations of the energy efficiency measures and the configurations of the photovoltaic systems are carried out in GenOpt. The results show that mid-rise social residential buildings are very close to reach the NZEB standard and through the optimized energy efficiency measures, the electric consumption of the building is reduced by up to $28 \%$. Therefore, mid-rise social residential buildings have potential to reach NZEB standard but other measures must be studied.
\end{abstract}

\section{Introduction}

Multiple evidences confirm that GHG are the main cause of global warming and the energy sector produces $64 \%$ of global GHG emissions (International Energy Agency, 2010). Building energy consumption currently accounts for $40 \%$ of total energy consumption in the USA and European Union (Cao, Dai, \& Liu, 2016). Specifically, the residential sector represents approximately $25 \%$ of global energy consumption and $17 \%$ of global $\mathrm{CO} 2$ emissions (U.S. Energy Information Amministration, 2016). In this scenario, the residential building sector would have a significant effect on the environment if the proper measurements and strategies are implemented (Nejat, Jomehzadeh, Taheri, Gohari, \& Muhd, 2015).

A Net Zero Energy Building means a grid connected building that has a high energy performance and the annual energy balance between imported energy of the grid and exported energy produced by on-site renewable system is zero (EU,2010; Jung, Paiho, Shemeikka, Lahdelma, \& Airaksinen, 2018). NZEB are a realistic solution for the mitigation of GHG emissions and reduction of energy use in building sector (Marszal et al., 2011). Recommendations and strategies to develop NZEB supported by studies might accelerate its large-scale implementation (Attia et al., 2017).

Through public policies focused on multiple scales (international, national and subnational), it is possible to respond to climate change with measures that promote NZEB. This needs to be complemented with scientific studies and different financing options that encourage its implementation (IPCC, 2014). Instead of using subsidies for building thermal renovations, how it happens in Chile, the government would provide subsidies for the implementation of NZEB (Toleikyte, Kranzl, \& Müller, 2018). However, in Chile there are no public policies towards the development of NZEB, which in part could be caused by the lack of technical and economic studies that support them.

The main aim of this study is evaluating the potential of mid-rise social residential buildings to reach NZEB standard in two climates of Chile represented by the cities of Santiago and La Serena. Santiago has a semi-arid climate (Bsk) and La Serena has a subtropical desert climate (Bwk).

\section{Methodology}

\section{Representative buildings}

To select the mid-rise (3-8 storeys) social residential representative buildings for the study, it starts with a revision of the building permits granted by the municipalities from 2012 and onwards for the communes of Quilicura, Providencia, San Joaquín, Ñuñoa, Pudahuel and Quinta Normal, which belong to the Metropolitan Region of Chile. The number of representative buildings is defined according to the Chilean standard NCh44Of.2007. The representative buildings are selected through a multi criteria matrix evaluating different architectural parameters that are obtained of the blueprints. In the matrix, the buildings are evaluated by each parameter and the buildings with the most typical characteristics are selected as representative. The parameters that are considered to define the representativeness are the following: 
- Regular geometry (RG)

- Built surface (BS)

- Window-Wall-Ratio (WWR)

- Number of storeys (NS)

- Available roof surface (AS)

- Number of departments (ND)

A 3D model for each representative building is made in SketchUp 2018 software in addition to Euclid 0.9.3 extension according to its blueprints. The architecture of the building is exported in ".idf" format, which is required for the building energy simulation.

\section{Modelling conditions}

Building energy simulations are carried out in EnergyPlus 8.7. The cities considered in the investigation correspond to La Serena with a subtropical desert climate (Bwk) and Santiago with a semi-arid climate (Bsk). The weather file of Santiago is obtained from EnergyPlus website and the weather file of La Serena is obtained from White Box Technologies's data. The envelope of each building is defined according to the requirements of the future Chilean standard NTM 011/2 2014. Table 1 shows the main characteristics defined for the elements of the envelope.

Table 1: Characteristics of envelope by city

\begin{tabular}{|c|c|}
\hline Cities & Main characteristics of envelope \\
\hline $\begin{array}{c}\mathrm{La} \\
\text { Serena }\end{array}$ & $\begin{array}{l}\text {-External walls: Concrete walls, } 0.2 \mathrm{~m} \text { thick, EPS } \\
40 \mathrm{~mm}, \mathrm{U}=0.77 \mathrm{~W} / \mathrm{m}^{2} \mathrm{~K} \\
\text {-Roof: Concrete slabs, } 0.2 \mathrm{~m} \text { thick, EPS } 80 \mathrm{~mm} \text {, } \\
\mathrm{U}=0.45 \mathrm{~W} / \mathrm{m}^{2} \mathrm{~K} \\
\text {-Ground floor: Concrete slabs, } 0.2 \mathrm{~m} \text { thick, EPS } \\
10 \mathrm{~mm}, \mathrm{U}=1.74 \mathrm{~W} / \mathrm{m}^{2} \mathrm{~K} \\
\text {-External windows: Double glazed window (4- } \\
12-4), \mathrm{U}=2.7 \mathrm{~W} / \mathrm{m}^{2} \mathrm{~K}, \mathrm{SHGC}=0.75 \\
\text {-Infiltration }=9 \mathrm{ACH} @ 50 \mathrm{~Pa}(\mathrm{NTM} 011 / 3 \text { ) }\end{array}$ \\
\hline Santiago & $\begin{array}{l}\text {-External walls: Concrete walls, } 0.2 \mathrm{~m} \text { thick, EPS } \\
60 \mathrm{~mm}, \mathrm{U}=0.56 \mathrm{~W} / \mathrm{m}^{2} \mathrm{~K} \\
\text {-Roof: Concrete slabs, } 0.2 \mathrm{~m} \text { thick, EPS } 100 \mathrm{~mm} \text {, } \\
\mathrm{U}=0.37 \mathrm{~W} / \mathrm{m}^{2} \mathrm{~K} \\
\text {-Ground floor: Concrete slabs, } 0.2 \mathrm{~m} \text { thick, EPS } \\
10 \mathrm{~mm}, \mathrm{U}=1.74 \mathrm{~W} / \mathrm{m}^{2} \mathrm{~K} \\
\text {-External windows: Double glazed window (4- } \\
12-4), \mathrm{U}=2.7 \mathrm{~W} / \mathrm{m}^{2} \mathrm{~K}, \mathrm{SHGC}=0.75 \\
\text {-Infiltration }=8 \mathrm{ACH} @ 50 \mathrm{~Pa}(\mathrm{NTM} 011 / 3 \text { ) }\end{array}$ \\
\hline
\end{tabular}

Schedules, modelling requirements and internal heat gains are obtained from the New Zealand Standard of thermal insulation for homes and small buildings NZS4218:2009. To ensure the thermal comfort of the occupants, all buildings consider the use of air source heat pump with a COP of 3 for cooling and 3 for heating respectively. Table 2 presents the main parameters and values considered in the building simulation.
Table 2: Parameters of modelling

\begin{tabular}{|c|c|}
\hline Category & Parameters \\
\hline Temperature control & Heating setpoint temperature: $20^{\circ} \mathrm{C}$ \\
& Cooling setpoint temperature: $25^{\circ} \mathrm{C}$ \\
HVAC systems & COP heating system: 3 \\
& COP cooling system: 3 \\
Occupants & Internal heat gain: $3 \mathrm{~W} / \mathrm{m}^{2}$ \\
Home appliances & Internal heat gain: $17.38 \mathrm{~W} / \mathrm{m}^{2}$ \\
Lighting & Internal heat gain: $7.12 \mathrm{~W} / \mathrm{m}^{2}$ \\
Domestic hot water & Output temperature: $60{ }^{\circ} \mathrm{C}$ \\
& Consumption: 28 liters/day*person \\
Ventilation & $0.5 \mathrm{ACH} @ 4 \mathrm{~Pa}$ \\
\hline
\end{tabular}

All equipment considered in the buildings uses electricity for its operation. The total electric consumption of each building is defined as the annual sum for HVAC, domestic hot water, lighting and home appliances. In this step, the base case of each building is evaluated and its electrical consumption is calculated.

\section{Optimization of energy efficiency measures}

To reach the NZEB standard, the buildings require high energy efficiency. In the second step, different energy efficiency measures are evaluated with the intent to increase the efficiency of the building. The optimized case considers the measures that allow to reduce the electric consumption to a minimum. The optimizations are carried out in GenOpt, which is a generic optimization software that allows to find the minimum value for a defined objective function. The main advantages of using this program are its successful applications in energy building simulations, its simple way of coupling with EnergyPlus and the short periods of time required for optimization. For this study, a hybrid meta-heuristic algorithm (Particle Swarm Optimization) and a pattern search algorithm (Hooke Jeeves) are used to solve the problem. The objective function is to minimize the electrical consumption of the building. Equation (1) shows the objective function considered in the study.

$$
F(x)=E_{H+} E_{C+} E_{A+} E_{D H W+} E_{L}
$$

$\mathrm{E}_{\mathrm{H}}$ : Electricity consumed by heating

$\mathrm{E}_{\mathrm{C}}$ Electricity consumed by cooling

$\mathrm{E}_{\mathrm{A} \text { : Electricity consumed by home appliances }}$

$\mathrm{E}_{\mathrm{DHW}}$ : Electricity consumed by domestic hot water

$\mathrm{E}_{\mathrm{L}}$ : Electricity consumed by lighting

GenOpt seeks the minimum electricity consumption of the building evaluating different combinations of the measures. The energy efficiency measures considered for this study are the following: using of different technologies for lighting and appliances, varing the SHGC and U-value of the windows, increasing thermal insulation of the envelope and changing the azimuth of buildings. For lighting are evaluated three kind of technologies: incandescent light, compact fluorescent light and led light. For appliances are considered conventional appliances and A++ appliances. 
Table 3 shows the range of values of parameters for the optimizations in both cities, La Serena (LS) and Santiago (S).

Table 3: Values of parameters for optimizations

\begin{tabular}{|c|c|c|c|c|c|}
\hline Parameters & City & Initial & Min & Max & Step \\
\hline $\begin{array}{c}\text { Thickness EPS } \\
\text { walls (mm) }\end{array}$ & LS & 40 & 40 & 60 & 10 \\
\cline { 2 - 6 } & S & 60 & 60 & 90 & 10 \\
\hline $\begin{array}{c}\text { Thickness EPS } \\
\text { roof (mm) }\end{array}$ & LS & 80 & 80 & 120 & 10 \\
\cline { 2 - 6 } & S & 100 & 100 & 150 & 10 \\
\hline $\begin{array}{c}\text { Thickness EPS } \\
\text { ground floor } \\
\text { (mm) }\end{array}$ & Both & 10 & 10 & 20 & 10 \\
\hline $\begin{array}{c}\text { Azimuth } \\
\text { (degree) }\end{array}$ & Both & 0 & 0 & 360 & 90 \\
\hline $\begin{array}{c}\text { U-value } \\
\text { windows } \\
(\text { W/m² } \text { K) }\end{array}$ & Both & 2.7 & 2.7 & 1.6 & 0.1 \\
\hline SHGC windows & Both & 0.75 & 0.05 & 0.85 & 0.1 \\
\hline
\end{tabular}

\section{Optimization of the photovoltaic system}

This study evaluates the use of photovoltaic panels (PV) on the roof as source of renewable energy. The objective of the optimization is to find the minimum area required by PV to meet the NZEB standard. The azimuth and the tilt of the panels are optimized to maximize the energy production; and the available surface for the photovoltaic system is restricted by the roof surface according to the building blueprints.

\section{NZEB potential}

The NZEB standard is met when there is a net equal to zero between the energy imported from the grid and the energy exported by renewable sources. The NZEB potential is defined according to the equation (2).

NZEB potential $=\frac{\text { Energy exported to the grid }}{\text { Energy imported from the grid }} * 100(2)$ Having a NZEB potential lower than $100 \%$ means that with the surface of photovoltaic panels, restricted to the maximum of the roof surface, it is not possible to achieve the NZEB standard, thus more energy is imported than exported. Having a NZEB potential of $100 \%$ means that the building complies with the NZEB standard.

\section{Results and Discussion}

\section{Representative buildings}

After the revision of the building permits granted by the different municipalities considered, 8 mid-rise social residential buildings are found. According to the $\mathrm{NCh} 44$ standard, which defines the representative size of the sample according to the total, 2 buildings are considered representative. With the blueprints and building permits of the 8 buildings, the parameters are calculated to find the 2 representative buildings that are evaluated in the next stages. Buildings A and B are the mid-rise social building representative of the study according to the score of the multi criteria matrix. A is a five-story building located in the municipality of San Joaquín with a built surface of $1262 \mathrm{~m}^{2}$. B is a five-story building located in the municipality of Quilicura with a built surface of 1102 $\mathrm{m}^{2}$. Table 4 shows the multi criteria matrix with the respective scores according to the position for each parameter and the total $(\mathrm{Sc})$.

Table 4: Multi criteria matrix with assigned scores

\begin{tabular}{|c|c|c|c|c|c|c|c|}
\hline Building & RG & BS & WWR & NS & AS & ND & Sc \\
\hline A & 4 & 4 & 3 & 4 & 4 & 4 & $\mathbf{2 3}$ \\
\hline B & 4 & 3 & 4 & 4 & 2 & 4 & $\mathbf{2 1}$ \\
\hline C & 3 & 4 & 4 & 2 & 3 & 3 & $\mathbf{1 9}$ \\
\hline D & 2 & 3 & 3 & 1 & 4 & 3 & $\mathbf{1 6}$ \\
\hline E & 3 & 2 & 2 & 3 & 3 & 2 & $\mathbf{1 5}$ \\
\hline F & 2 & 1 & 1 & 3 & 2 & 2 & $\mathbf{1 1}$ \\
\hline G & 1 & 2 & 1 & 2 & 1 & 1 & $\mathbf{8}$ \\
\hline H & 1 & 1 & 2 & 1 & 1 & 1 & $\mathbf{7}$ \\
\hline
\end{tabular}

Figures 1 and 2 presents the 3D models of both buildings according to their respective blueprints.

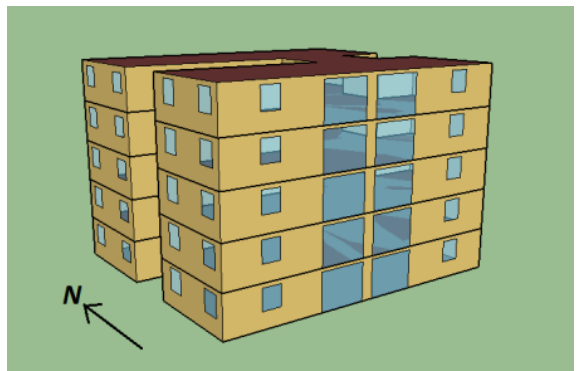

Figure 1: 3D model for building A

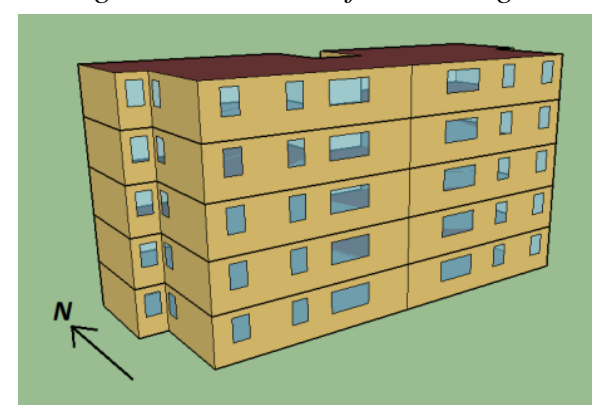

Figure 2: 3D model for building $B$

\section{Optimization of building energy performance}

For the base cases, the main consumptions in the mid-rise social residential buildings are home appliances and domestic hot water. Both categories use approximately $65-70 \%$ of the total electricity consumption of the building. The low consumption of HVAC system in comparison with the other type of uses is due to the equipment used for both heating and cooling are of high efficiency and presents a COP of 3 . In La Serena, the base cases consume $60-62 \mathrm{kWh} / \mathrm{m}^{2}$ year; and in Santiago, the base cases consume $66-70 \mathrm{kWh} / \mathrm{m}^{2}$ year.

The following figures present the results of the annual electricity consumption for the base case building, the annual electricity consumption of the optimized case and the percentage of reduction that is achieved with the optimal energy efficiency measures. Figures 3 and 4 shows the results for La Serena, while Figures 5 and 6 shows the results for Santiago. 


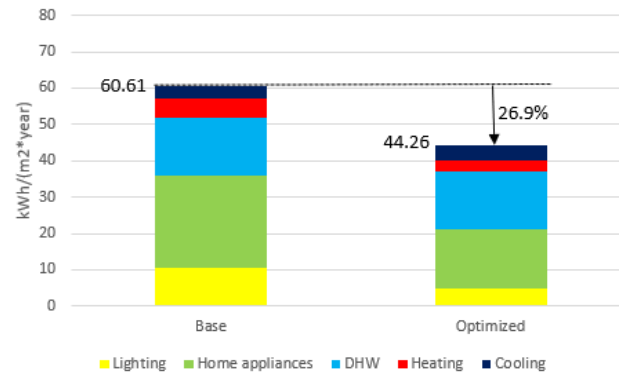

Figure 3: Electric consumption for building $A-L a$ Serena

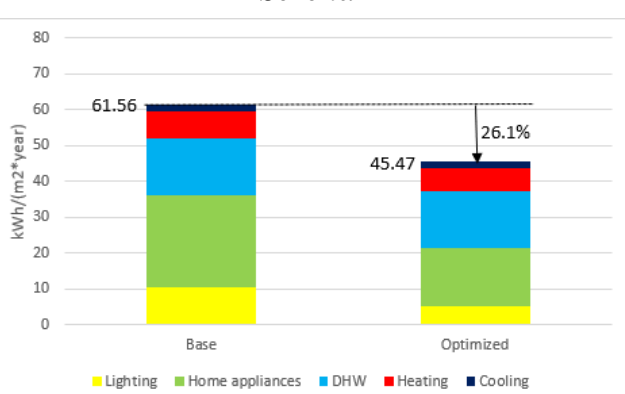

Figure 4: Electric consumption for building $B-L a$ Serena

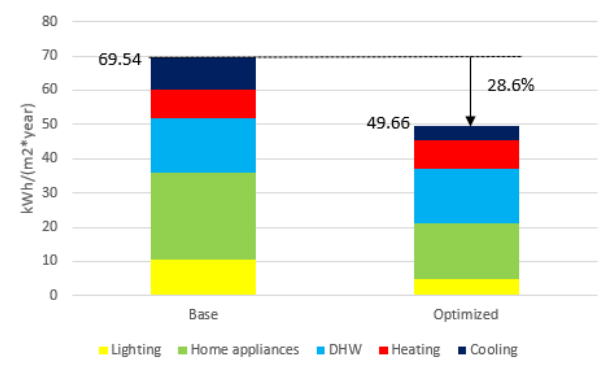

Figure 5: Electric consumption for building A - Santiago

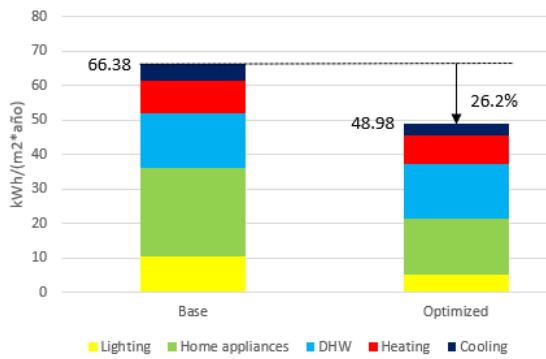

Figure 6: Electric consumption for building B Santiago

The annual electricity consumption is reduced between $26.1 \%$ and $28.6 \%$ in comparison to the base case by using optimized building energy efficiency strategies. For all cities, the maximum insulation thicknesses of all the elements of the envelope are selected. Also, lighting systems and home appliances with the lowest electricity consumption, as is the case of LED and A ++ equipment, respectively. While SHGC of the windows is the only parameter that varies according to the building and the city evaluated.

Table 5 shows the parameters of the optimization that allow reducing electricity consumption to a minimum.
Table 5: Optimum design parameters of building $A$ and $B$

\begin{tabular}{|c|c|c|c|c|}
\hline \multirow{2}{*}{ Parameters } & \multicolumn{2}{|c|}{ LS } & \multicolumn{2}{c|}{ S } \\
\cline { 2 - 5 } & A & B & A & B \\
\hline Thickness EPS walls (mm) & 60 & 60 & 90 & 90 \\
\hline Thickness EPS roof (mm) & 120 & 120 & 150 & 150 \\
\hline $\begin{array}{c}\text { Thickness EPS ground floor } \\
\text { (mm) }\end{array}$ & 20 & 20 & 20 & 20 \\
\hline Azimuth (degree) & 0 & 0 & 0 & 0 \\
\hline U-value windows (W/m² $\mathrm{K})$ & 1.6 & 1.6 & 1.6 & 1.6 \\
\hline SHGC windows & 0.75 & 0.85 & 0.55 & 0.75 \\
\hline Lighting & LED & LED & LED & LED \\
\hline Home appliances & A++ & A++ & A++ & A++ \\
\hline
\end{tabular}

\section{Potential to reach NZEB standard}

For all cases, it is observed that the mid-rise social residential representative buildings do not comply with the NZEB standard although they have the entire roof surface used with photovoltaic panels. However, they are close to achieve this standard. For La Serena and Santiago, the NZEB potential of these buildings varies between $91 \%$ and $95 \%$. Table 6 shows the potential to reach NZEB standard for each case and some characteristics of the photovoltaic system considered.

\begin{tabular}{|c|c|c|c|c|}
\hline & \multicolumn{2}{|c|}{$\mathbf{L S}$} & \multicolumn{2}{|c|}{$\mathbf{S}$} \\
\hline & A & B & $\mathbf{A}$ & $\mathbf{B}$ \\
\hline $\begin{array}{l}\text { Available roof surface } \\
\left(\mathrm{m}^{2}\right)\end{array}$ & 251 & 220 & 251 & 220 \\
\hline PV surface $\left(\mathrm{m}^{2}\right)$ & 251 & 220 & 251 & 220 \\
\hline Tilt angle PV & $0^{\circ}$ & $0^{\circ}$ & $0^{\circ}$ & $0^{\circ}$ \\
\hline Energy imported (MWh) & 55.69 & 50.1 & 62.67 & 53.97 \\
\hline Energy exported (MWh) & 52.2 & 45.75 & 58.39 & 51.18 \\
\hline NZEB potential (\%) & 94 & 91 & 93 & 95 \\
\hline
\end{tabular}

\section{Conclusion}

Two mid-rise social residential buildings are selected as representative for this study. The envelope of the buildings considers the thermal energy requirements of the NTM-11 future Chilean standard for residential buildings. The buildings for the base case (without energy efficiency measures) consume $60 \mathrm{kWh} / \mathrm{m}^{2} /$ year in La Serena and $70 \mathrm{kWh} / \mathrm{m}^{2} /$ year in La Santiago. With the optimized strategies to reduce the electrical consumption of buildings, the annual electricity consumption of the base case building is reduced up to $28.6 \%$. The mid-rise social residential buildings are very close to reach the NZEB standard through optimized energy efficiency measures and a photovoltaic system locates on the roof.

Although the climate conditions between the cities evaluated are different, the NZEB potential of the representative buildings are quite similar. For the correct development of public policies that encourage the implementation of the NZEB, more cities should be studied due to the diversity of climates throughout Chile.

In order to achieve the NZEB standard, more strategies should be studied to reduce electricity consumption, such 
as integration of DHW with PV and HVAC, increase the roof surface, or even evaluate the incorporation of photovoltaic panels on vertical facades.

\section{Acknowledgement}

The authors are grateful for the funding of the research project "Interdisciplina II5035" of Vicerectoría de Investigación de la Pontificia Universidad Católica de Chile

\section{Nomenclature}

\begin{tabular}{|l|l|}
\hline NZEB & Net Zero Energy Building \\
\hline RG & Regular geometry \\
\hline BS & Built surface \\
\hline WWR & Window Wall Ratio \\
\hline NS & Number of storeys \\
\hline AS & Available roof surface \\
\hline ND & Number of departments \\
\hline Sc & Total score \\
\hline LS & La Serena \\
\hline$S$ & Santiago \\
\hline PV & Photovoltaic panel \\
\hline$E_{H}$ & Electricity consumed by heating \\
\hline$E_{C}$ & Electricity consumed by cooling \\
\hline$E_{A}$ & Electricity consumed by home appliances \\
\hline$E_{D H W}$ & $\begin{array}{l}\text { Electricity consumed by domestic hot } \\
\text { water }\end{array}$ \\
\hline$E_{\mathrm{L}}$ & Electricity consumed by lighting \\
\hline
\end{tabular}

\section{References}

Attia, S., Eleftheriou, P., Xeni, F., Morlot, R., Ménézo, C., Kostopoulos, V., ... Hidalgo-Betanzos, J. M. (2017). Overview and future challenges of nearly zero energy buildings (nZEB) design in Southern Europe. Energy and Buildings, 155, 439-458.

Cao, X., Dai, X., \& Liu, J. (2016). Building energyconsumption status worldwide and the state-of-the-art technologies for zero-energy buildings during the past decade. Energy \& Buildings, 128, 198-213.

Department of Building and Housing. (2009). Thermal Insulation - Housing and Small Buildings - NZS 4218:2009.

EU. (2010). Directive 2010/31/EU of the European Parliament and of the Council. Official Journal of the European Union, 13-35.
Instituto Nacional de Normalización. (2007). Procedimientos de muestreo para inspección por atributos - Planes de muestreo indexados por nivel de calidad aceptable (AQL) para la inspección lote por lote. NCh44: Of.2007. Santiago, Chile.

Instituto Nacional de Normalización. (2007). Acondicionamiento térmico - Envolvente térmica de edificios - Cálculo de resistencias y transmitancias térmicas. NCh853: Of.2007. Santiago, Chile.

Instituto Nacional de Normalización. (2008). Comportamiento térmico de edificios - Transmisión de calor por el terreno - Métodos de cálculo. NCh3117: Of.2008. Santiago, Chile.

International Energy Agency. (2010). World Energy Outlook 2009. World Energy Outlook, 23(4), 326328.

IPCC. (2014). Climate Change 2014 Synthesis Report Summary Chapter for Policymakers. Ipcc, 31.

Jung, N., Paiho, S., Shemeikka, J., Lahdelma, R., \& Airaksinen, M. (2018). Energy performance analysis of an office building in three climate zones. Energy and Buildings, 158, 1023-1035.

Marszal, A. J., Heiselberg, P., Bourrelle, J. S., Musall, E., Voss, K., Sartori, I., \& Napolitano, A. (2011). Zero Energy Building - A review of definitions and calculation methodologies. Energy and Buildings, 43(4), 971-979.

MINVU. (2014). NTM 11/2 Requisitos y mecanismos de acreditación para acondicionamiento ambiental de las edificaciones. Parte 2: Comportamiento higrotérmico.

MINVU. (2014). NTM 11/3 Requisitos y mecanismos de acreditación para acondicionamiento ambiental de las edificaciones . Parte 3: Calidad del aire interior.

Nejat, P., Jomehzadeh, F., Taheri, M. M., Gohari, M., \& Muhd, M. Z. (2015). A global review of energy consumption, CO2emissions and policy in the residential sector (with an overview of the top ten CO2emitting countries). Renewable and Sustainable Energy Reviews, 43, 843-862.

Toleikyte, A., Kranzl, L., \& Müller, A. (2018). Cost curves of energy efficiency investments in buildings Methodologies and a case study of Lithuania. Energy Policy, 115(January), 148-157.

U.S. Energy Information Amministration. (2016). International Energy Outlook 2016 (Vol. 0484). 